Kongunadu Arts and Science College, Coimbatore.

\title{
INDUCTION OF CALLOGENESIS AND SHOOT REGENERATION OF A MEDICINAL PLANT SPECIES PERISTROPHE BICALYCULATA (RETZ.) NEES.
}

\author{
Femila Jose, V. and R. Asir Selin Kumar* \\ PG and Research Department of Botany, Scott Christian College, \\ Nagercoil - 629 003, Tamilnadu, India. \\ *E.mail: asirselin@gmail.com
}

\section{ABSTRACT}

In the present study, protocol for callus induction and regeneration for the medicinal plant species, Peristrophe bicalyculata (Retz.)Nees has been developed by using leaf explants. Young apical leaf explant was

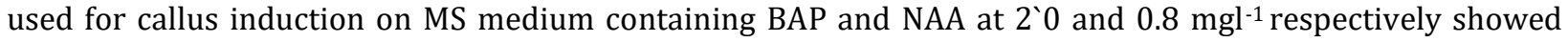
maximum callus induction (80\%). The amount of callus responded for shoot formation $(81 \%)$ was obtained in the MS medium containing BAP $\left(2.0 \mathrm{mgl}^{-1}\right)$ and $\mathrm{GA}_{3}\left(0.3 \mathrm{mgl}^{-1}\right)$.The elongated shoots were rooted on half strength medium supplemented with IBA $\left(2.0 \mathrm{mgl}^{-1}\right)$ and IAA $\left(0.2 \mathrm{mgl}^{-1}\right)$ for shoots rooted. Regenerated plantlet were successfully acclimatized and hardened off inside the culture and then transferred to green house with better survival rate.

Keywords: Peristrophe bicalyculata, MS medium, multiple shooting, Acclimatization.

\section{INTRODUCTION}

The world has a very rich biodiversity of woody plants, many of which are medicinally important. Because of the use in medicine, woody plants require rapid and reliable methods of propagation. The conventional methods of propagation such as cuttings, graftings and layering are very slow. The rapid loss of rooting ability with age of woody plants makes them difficult to propagate. So, they require alternative method. Plant propagation by tissue culture is the possible approach to overcome the problem.

Peristrophe bicalyculata (Retz.)Nees belonging to the family Acanthaceae, having lot of medicinal properties. The plant is used on blood pressure, kidney, liver functions and skin related problems. It is also used as an antidote for snake poison when macerated in an infusion of rice, and as an insect repellant (Dwivedi, 2008). The ethanol extract of the plant has been reported to exhibit analgesic, anti-inflammatory and antibacterial properties (Chopra, 1959; Dwivedi, 2002). Although undocumented, the plant is used in South West Nigeria in the treatment of hypertension and other cardiovascular diseases. The essential oil shows tuberculostatic activity in vitro. Ayurvedic pharmacopoeia of India recommends the dried root in insomnia and for fear- psychosis in children. Leaves of the plant were used traditionally as analgesic, antipyretic, anti-inflammatory, sedative, stomachic, anticancer, fertility, diuretics and diarrhoea.
To date, there has been no report on in vitro regeneration of $P$. bicalyculata. Herein, we described the optimization of culture conditions and plant growth regulators required for callus initiation, shoot regeneration and rooting of plantlets from immature leaflets of $P$. bicalyculata.

\section{MATERIALS AND METHODS}

Leaf segments from young and healthy branches of $P$. bicalyculata were used as explants. They were collected from pot cultured individuals maintained in a mist chamber. For surface sterilization, the collected immature leaves were washed with tap water twice and then treated with 5 $\%$ tween-20 solutions for 5 min followed by rinsing in tap water. To eliminate fungal contamination, explants were further treated with $5 \%$ antibiotics (Amphicillin and Rifampicin) for $30 \mathrm{~min}$ followed by 3 rinses in sterile double distilled water. Further, surface sterilization was carried out by dipping the explants in $0.1 \% \mathrm{HgCl}_{2}$ for $3 \mathrm{~min}$ followed by $3-4$ rinses in sterile double distilled water.

\subsection{Media and culture condition}

Murashige and Skoog (MS) (1962), medium containing $3 \%$ sucrose solidified with $1 \%$ agar (tissue culture grade, Himedia, India) was used. The $\mathrm{pH}$ of the medium was adjusted to 5.6-5.8 prior to the addition of agar before autoclaving at $121^{\circ} \mathrm{C}$ for $15 \mathrm{~min}$. All the culture bottles were kept in culture chamber at $25 \pm 2^{0} \mathrm{C}$ under $16 / 8 \mathrm{hr}$ (light/dark) photoperiod with a light intensity of 2000 lux 
supplied by cool white fluorescent tubes and with $60-65 \%$ relative humidity.

\subsection{Callus induction medium}

The explants were transferred to culture bottles containing $25 \mathrm{ml}$ MS medium supplemented with different concentrations and combinations of BAP and NAA for callus induction.

\subsection{Shoot induction medium}

MS medium containing different concentrations and combinations of BAP $(0.5,1.0$, $1.5,2.0,2.5$ and $3.0 \mathrm{mg} / \mathrm{l}$ ) and $\mathrm{GA}_{3}$ at $0.3 \mathrm{mg} / \mathrm{l}$ was used for shooting attributes.

\subsection{Rooting of elongated shoots and acclimatization}

After proper shoot induction, the plantlets were carefully removed from the medium and washed with sterilize double distilled water properly, so as to avoid any trace of medium on roots. In vitro regenerated shoots (5-6 cm long) were excised and transferred onto the rooting media containing half strength MS medium supplemented with IBA and IAA for rooting. After proper root formation, these rooted plantlets were transferred to hardening medium composed by garden soil, sand and vermicompost in different proportion and maintained in greenhouse condition to know the survivability rate.

\subsection{Statistical Analysis}

All the experiment was done at least twice using triplicate. The data was statistically processed and means were compared using Duncan's Multiple Range Test $(P<0.05)$.

\section{RESULTS AND DISCUSSION}

Calli formation was observed in leaf explants after 25 days. The best response of callus $(80 \%)$ was observed in the MS medium supplemented with cytokinin BAP $\left(2.0 \mathrm{mgl}^{-1}\right)$ and auxin, NAA (0.8 $\left.\mathrm{mgl}^{-1}\right)$ (Table 1$)$. The result is supported by Thambiraj \& Paulsamy (2012).Further studies were carried out for shoot regeneration capacity of the callus. Shoots were initiated from the callus obtained leaf explants. The best result of shooting $(81 \%)$ was observed on the MS medium fortified with BAP $\left(2.0 \mathrm{mgl}^{-1}\right)$ and $\mathrm{GA}_{3}\left(0.3 \mathrm{mgl}^{-1}\right)$. The maximum number of multiple shoots 11.77 shoots/callus \& shoot length $(6.3 \mathrm{~cm})$ were produced in the same concentrations and combinations of growth regulators (Table 2). The superiority of BAP over the other cytokinins on shoot bud production and proliferation of shoots has been reported for several medicinal and aromatic plant species by Jebakumar \& Jayabalan, 2000; Hussain \& Anis, 2006; Raja et al., 2008; Faisal \& Anis, 2003.

Induction of rooting is an important step for in vitro plant propagation. Excised shoots were inoculated on MS medium with IBA and IAA for proper root development. The rooting responses were summarized in Table 3. Maximum rooting (78\%), number of roots (9.78 roots/ shoot) \& root length $(6.6 \mathrm{~cm})$ was observed on the MS medium supplemented with IBA and IAA at $2.0 \& 0.2 \mathrm{mgl}^{-1}$ respectively (Table 3 ). These findings are in agreement with those reported by Sujatha \& Reddy, 1998; Ahn et al., 2007; Alam et al., 2010 and Ramanathan et al., 2011.

After the development of roots, the plantlets were taken out from the culture bottles and washed with sterilized distilled water to remove adhering agar medium, so that the chance of contamination could be stopped. Then these juvenile plantlets were transferred to the hardening medium containing garden soil, sand and vermicompost (1:1:1 ratio by volume) where the leaf callus derived plantlets survivability rate was higher $76 \%$ (Table 4). Admixture of all these three components may offer condusive environment by providing proper nutrients, adequate aeration and required minerals respectively to the plantlets.

Table 1. Effect of growth regulators on callus induction from leaf explants of the species, Peristrophe bicalyculata.

\begin{tabular}{cccccc}
\hline \multicolumn{2}{c}{ Growth regulators (mg/l) } & \multicolumn{2}{c}{$\begin{array}{c}\text { Days required for callus } \\
\text { formation after inoculation }\end{array}$} & Callus formation (\%) \\
\hline BAP & 2,4-D & NAA & Kn & Leaf Explant & Leaf Explant \\
\hline 0.5 & 0.0 & 0.0 & 0.0 & 18 & $35.25^{\mathrm{a}} \pm 1.63$ \\
1.0 & 0.0 & 0.0 & 0.0 & 19 & $47.76^{\mathrm{c}} \pm 0.82$ \\
1.5 & 0.0 & 0.0 & 0.0 & 17 & $56.86^{\mathrm{e}} \pm 1.63$ \\
2.0 & 0.0 & 0.0 & 0.0 & 20 & $64.35^{\circ} \pm 2.45$ \\
2.5 & 0.0 & 0.0 & 0.0 & 21 & $70.53^{\mathrm{i}} \pm 0.82$ \\
\hline
\end{tabular}




\begin{tabular}{cccccc}
\hline 3.0 & 0.0 & 0.0 & 0.0 & 19 & $60.84^{\mathrm{f}} \pm 0.82$ \\
0.0 & 0.5 & 0.4 & 0.0 & 16 & $46.57^{\mathrm{c}} \pm 1.63$ \\
0.0 & 1.0 & 0.4 & 0.0 & 15 & $54.37^{\mathrm{e}} \pm 1.63$ \\
0.0 & 1.5 & 0.4 & 0.0 & 20 & $61.36^{\mathrm{f}} \pm 0.82$ \\
0.0 & 2.0 & 0.4 & 0.0 & 23 & $69.58^{\mathrm{i}} \pm 1.63$ \\
0.0 & 2.5 & 0.4 & 0.0 & 16 & $37.97^{\mathrm{a}} \pm 1.63$ \\
0.5 & 0.0 & 0.2 & 0.0 & 15 & $59.00^{\mathrm{cd}} \pm 0.82$ \\
1.0 & 0.0 & 0.4 & 0.0 & 16 & $67.35^{\mathrm{e}} \pm 1.63$ \\
1.5 & 0.0 & 0.6 & 0.0 & 21 & $75.35^{\mathrm{i}} \pm 0.82$ \\
2.0 & 0.0 & 0.8 & 0.0 & 25 & $80.13^{\mathrm{j}} \pm 1.63$ \\
2.5 & 0.0 & 1.0 & 0.0 & 21 & $72.25^{\mathrm{h}} \pm 1.63$ \\
3.0 & 0.0 & 1.2 & 0.0 & 18 & $52.87^{\mathrm{b}} \pm 1.63$ \\
0.0 & 0.3 & 0.0 & 0.2 & 15 & $46.48^{\mathrm{c}} \pm 1.63$ \\
0.0 & 0.6 & 0.0 & 0.4 & 17 & $51.59^{\mathrm{d}} \pm 0.82$ \\
0.0 & 0.9 & 0.0 & 0.6 & 16 & $55.32^{\mathrm{e}} \pm 1.63$ \\
0.0 & 1.2 & 0.0 & 0.8 & 18 & $60.21^{\mathrm{f}} \pm 0.82$ \\
0.0 & 1.5 & 0.0 & 1.0 & 14 & $49.00^{\mathrm{cd} \pm 0.82}$ \\
\hline
\end{tabular}

Means in columns followed by different letter (s) are significant to each other at 5\% level according to DMRT.

Table 2. Effect of different concentrations of growth regulators on shoot initiation, shoot number and shoot length after the subculturing of leaf derived callus of the species, Peristrophe bicalyculata.

\begin{tabular}{|c|c|c|c|c|c|c|}
\hline \multicolumn{4}{|c|}{ Growth regulators (mg/l) } & \multirow[t]{2}{*}{ Culture response (\%) } & \multirow[t]{2}{*}{ No. of shoots/callus } & \multirow[t]{2}{*}{ Shoot length (cm) } \\
\hline BAP & NAA & $\mathbf{G A}_{3}$ & IAA & & & \\
\hline 0.3 & 0.0 & 0.0 & 0.0 & $53.23^{\mathrm{d}} \pm 0.82$ & $3.14^{\mathrm{ab}} \pm 0.82$ & $2.5^{\mathrm{ab}} \pm 0.82$ \\
\hline 0.3 & 0.0 & 0.0 & 0.0 & $62.64^{\mathrm{hi}} \pm 0.82$ & $5.74^{\mathrm{bcd}} \pm 0.82$ & $3.8^{\mathrm{abc}} \pm 1.63$ \\
\hline 0.3 & 0.0 & 0.0 & 0.0 & $65.78^{j} \pm 1.63$ & $7.98^{\mathrm{def}} \pm 1.63$ & $4.0^{\mathrm{abc}} \pm 1.63$ \\
\hline 0.3 & 0.0 & 0.0 & 0.0 & $58.37^{\mathrm{fg}} \pm 0.82$ & $4.00^{\mathrm{abc}} \pm 1.63$ & $5.2^{\mathrm{bc}} \pm 0.82$ \\
\hline 0.3 & 0.0 & 0.0 & 0.0 & $60.64^{\mathrm{gh}} \pm 1.63$ & $9.38^{\mathrm{fgh}} \pm 1.63$ & $4.6^{\mathrm{abc}} \pm 0.82$ \\
\hline 0.3 & 0.0 & 0.0 & 0.0 & $70.53 \mathrm{kl} \pm 1.63$ & $9.64^{\mathrm{fgh}} \pm 0.82$ & $5.7^{c} \pm 1.63$ \\
\hline 0.5 & 0.0 & 0.3 & 0.0 & $69.27^{\mathrm{k}} \pm 0.82$ & $8.75^{\mathrm{hi}} \pm 1.63$ & $4.3^{\mathrm{abc}} \pm 0.82$ \\
\hline 1.0 & 0.0 & 0.3 & 0.0 & $75.00^{\mathrm{m}} \pm 1.63$ & $9.35^{\mathrm{ghi}} \pm 0.82$ & $3.9 \mathrm{abc} \pm 0.82$ \\
\hline 1.5 & 0.0 & 0.3 & 0.0 & $77.58^{\mathrm{n}} \pm 0.82$ & $10.17^{i} \pm 0.82$ & $5.0^{c} \pm 1.63$ \\
\hline 2.0 & 0.0 & 0.3 & 0.0 & $81.58^{n} \pm 0.82$ & $11.77^{\mathrm{i}} \pm 0.82$ & $6.3^{c} \pm 1.63$ \\
\hline 2.5 & 0.0 & 0.3 & 0.0 & $75.96^{\mathrm{b}} \pm 1.63$ & $9.98^{\mathrm{efg}} \pm 0.82$ & $5.7^{a b c} \pm 0.82$ \\
\hline 3.0 & 0.0 & 0.3 & 0.0 & $50.36^{\mathrm{a}} \pm 1.63$ & $5.32^{\mathrm{bcd}} \pm 0.82$ & $2.5^{\mathrm{ab}} \pm 0.82$ \\
\hline 0.0 & 0.5 & 0.0 & 0.0 & $55.26^{\mathrm{de}} \pm 0.82$ & $6.41^{\mathrm{ghi}} \pm 0.82$ & $3.5^{\mathrm{abc}} \pm 1.63$ \\
\hline 0.0 & 0.5 & 0.0 & 0.0 & $41.12^{\mathrm{a}} \pm 0.82$ & $5.67^{\mathrm{fgh}} \pm 0.82$ & $4.9 \mathrm{bc} \pm 0.82$ \\
\hline 0.0 & 0.5 & 0.0 & 0.0 & $49.11^{\mathrm{c}} \pm 0.82$ & $6.52^{\text {cde }} \pm 1.63$ & $5.3^{b c} \pm 1.63$ \\
\hline 0.0 & 0.5 & 0.0 & 0.0 & $58.85^{\mathrm{fg}} \pm 1.63$ & $3.43^{\mathrm{ab}} \pm 1.63$ & $4.7 \mathrm{abc} \pm 1.63$ \\
\hline 0.0 & 0.5 & 0.0 & 0.0 & $64.26^{\mathrm{ij}} \pm 0.82$ & $5.28^{b c d} \pm 0.82$ & $3.3^{\mathrm{abc}} \pm 0.82$ \\
\hline 0.0 & 0.5 & 0.0 & 0.0 & $72.16^{1} \pm 1.63$ & $7.47^{\mathrm{efg}} \pm 1.63$ & $2.8^{\mathrm{ab}} \pm 0.82$ \\
\hline 0.5 & 0.0 & 0.0 & 0.2 & $43.49 \mathrm{~d} \pm 0.82$ & $3.90^{\operatorname{def}} \pm 0.82$ & $2.0^{a b c} \pm 0.82$ \\
\hline 1.0 & 0.0 & 0.0 & 0.2 & $28.00^{\mathrm{k}} \pm 1.63$ & 1.38 ghi \pm 0.82 & $1.9 \mathrm{a} \pm 0.82$ \\
\hline 1.5 & 0.0 & 0.0 & 0.2 & $57.45^{\mathrm{ef}} \pm 1.63$ & $4.15^{\mathrm{abc}} \pm 1.63$ & $3.4^{\mathrm{abc}} \pm 0.82$ \\
\hline 2.0 & 0.0 & 0.0 & 0.2 & $62.75^{\mathrm{hi}} \pm 0.82$ & $2.47 \mathrm{a} \pm 0.82$ & $3.5^{\mathrm{abc}} \pm 1.63$ \\
\hline 2.5 & 0.0 & 0.0 & 0.2 & $59.32 \mathrm{fg} \pm 0.82$ & $3.74 \mathrm{ab} \pm 1.63$ & $2.0^{\mathrm{a}} \pm 0.82$ \\
\hline 3.0 & 0.0 & 0.0 & 0.2 & $55.211^{\mathrm{ij}} \pm 1.63$ & $6.00^{\mathrm{fgh}} \pm 0.82$ & $2.5^{\mathrm{ab}} \pm 0.82$ \\
\hline
\end{tabular}

Means in columns followed by different letter (s) are significant to each other at 5\% level according to DMRT. 
Table 3. Effect of different concentrations of growth regulators on root number, rooting percentage and root length after the subculturing of leaf callus derived in vitro produced shoots of the species, Peristrophe bicalyculata.

\begin{tabular}{|c|c|c|c|c|c|}
\hline \multicolumn{3}{|c|}{ Growth regulators $(\mathrm{mg} / \mathrm{l})$} & \multirow{2}{*}{ Chonte rontad $(0 /$ ) } & \multirow[t]{2}{*}{ No. of roots/shoot } & \multirow[t]{2}{*}{ Root length (cm) } \\
\hline IBA & IAA & NAA & & & \\
\hline 0.5 & 0.2 & 0.0 & $60.30^{j} \pm 0.41$ & $6.67^{\mathrm{abc}} \pm 0.82$ & $5.4^{\mathrm{a}-\mathrm{d}} \pm 0.82$ \\
\hline 1.0 & 0.2 & 0.0 & $68.25^{\mathrm{k}} \pm 0.82$ & $7.39 \mathrm{def} \pm 1.63$ & $5.9^{\mathrm{ef}} \pm 0.82$ \\
\hline 1.5 & 0.2 & 0.0 & $76.29^{\mathrm{m}} \pm 0.41$ & $8.81^{\mathrm{f}} \pm 1.63$ & $6.0^{f} \pm 1.63$ \\
\hline 2.0 & 0.2 & 0.0 & $78.65^{1} \pm 0.82$ & $9.78^{\mathrm{ef}} \pm 0.41$ & $6.6^{\mathrm{ef}} \pm 1.63$ \\
\hline 2.5 & 0.2 & 0.0 & $62.54^{\mathrm{h}} \pm 1.63$ & $4.98^{\mathrm{abc}} \pm 0.82$ & $4.8^{\mathrm{de}} \pm 0.41$ \\
\hline 3.0 & 0.2 & 0.0 & $48.45^{g} \pm 0.82$ & $3.00^{\mathrm{ab}} \pm 0.82$ & $3.2^{\mathrm{a}-\mathrm{d}} \pm 0.16$ \\
\hline 0.5 & 0.0 & 0.3 & $19.65^{\mathrm{e}} \pm 0.41$ & $2.26^{\mathrm{bcd}} \pm 1.63$ & $1.1^{\mathrm{bcd}} \pm 0.82$ \\
\hline 1.0 & 0.0 & 0.3 & $25.32^{\mathrm{d}} \pm 0.82$ & $3.19^{a b} \pm 1.63$ & $3.9^{\mathrm{a}-\mathrm{d}} \pm 0.33$ \\
\hline 1.5 & 0.0 & 0.3 & $35.54^{c} \pm 1.63$ & $4.64^{\mathrm{abc}} \pm 0.82$ & $2.8^{\mathrm{abc}} \pm 0.49$ \\
\hline 2.0 & 0.0 & 0.3 & $39.24^{b} \pm 0.82$ & $4.38^{\mathrm{abc}} \pm 0.33$ & $3.5^{\mathrm{a}-\mathrm{d}} \pm 0.41$ \\
\hline 2.5 & 0.0 & 0.3 & $45.17^{a} \pm 0.41$ & $2.59^{a} \pm 0.82$ & $2.6^{\mathrm{ab}} \pm 0.82$ \\
\hline 3.0 & 0.0 & 0.3 & $50.98^{a} \pm 0.82$ & $3.38^{\mathrm{ab}} \pm 0.82$ & $2.2^{\mathrm{a}} \pm 0.16$ \\
\hline 0.5 & 0.0 & 0.0 & $34.87^{c} \pm 0.82$ & $3.29^{\mathrm{ab}} \pm 1.63$ & $3.8^{\mathrm{a}-\mathrm{d}} \pm 0.82$ \\
\hline 1.0 & 0.0 & 0.0 & $45.67^{\mathrm{f}} \pm 0.82$ & $5.48^{\mathrm{bcd}} \pm 0.49$ & $2.9 \mathrm{abc} \pm 0.82$ \\
\hline 1.5 & 0.0 & 0.0 & $52.54^{\mathrm{h}} \pm 1.63$ & $6.76^{\text {cde }} \pm 1.63$ & $4.1^{\mathrm{bcd}} \pm 0.82$ \\
\hline 2.0 & 0.0 & 0.0 & $51.87^{\mathrm{h}} \pm 0.82$ & $5.53^{\mathrm{bcd}} \pm 0.82$ & $4.5^{\text {cde }} \pm 0.41$ \\
\hline 2.5 & 0.0 & 0.0 & $48.88^{g} \pm 0.41$ & $4.68^{\mathrm{abc}} \pm 0.82$ & $3.2^{\mathrm{a}-\mathrm{d}} \pm 0.33$ \\
\hline 3.0 & 0.0 & 0.0 & $55.34^{\mathrm{i}} \pm 0.82$ & $5.58^{\mathrm{bcd}} \pm 0.82$ & $4.8^{\mathrm{de}} \pm 0.24$ \\
\hline
\end{tabular}

Means in columns followed by different letter (s) are significant to each other at 5\% level according to DMRT.

Table 4. Effect of different composition of hardening medium on survivability rate of leaf callus derived in vitro rooted plantlets of the species, Peristrophe bicalyculata.

\begin{tabular}{lccc}
\hline Hardening medium composition (V/V) & $\begin{array}{c}\text { No. of plantlets } \\
\text { under hardening }\end{array}$ & $\begin{array}{c}\text { No. of } \\
\text { plantlets } \\
\text { survived }\end{array}$ & Survivability (\%) \\
\hline Red soil + sand (1:1) & 50 & 24 & $42^{\mathrm{a}} \pm 0.82$ \\
Garden soil + sand + vermicompost (1:1:1) & 50 & 41 & $76^{\mathrm{d}} \pm 0.41$ \\
Decomposed coir waste + perlite + compost & 50 & 35 & $71^{\mathrm{c}} \pm 1.63$ \\
(1:1:1) & 50 & 33 & $64^{\mathrm{b}} \pm 0.65$ \\
Rermicompost + soil (1:1) & 50 & 25 & $50^{\mathrm{a}} \pm 0.82$ \\
\hline
\end{tabular}

Means in column followed by different letter (s) are significant to each other at $5 \%$ level according to DMRT. 
From the above study, it is concluded that multiple shoot and root cultures of Peristrophe bicalyculata were established from leaf explants on MS medium supplemented with combination of hormones. This protocol has potential for large-scale micropropagation and application in molecular plant breeding research programs.

\section{REFERENCES}

Dwivedi, S. (2008). Ethnomedicinal uses of some plants species by ethnic and rural peoples of indore district of Madhya Pradesh India (online). Available from: http:// pharmainfo.net.

Chopra, H. (1959). Medicinal Herbs of Chhattisgarh, India Having Less known Traditional Uses. Retrieved from: http: // www. Botanical. com.

Dwivedi, S. (2002). Ethnomedicinal Uses of Some Plant Species by Ethnic and Rural Peoples of Indore District of Madhya Pradesh, India. Retrieved from: http: // www. Pharmainfo. net.

Murashige, T. and F. Skoog, (1962). A revised medium for rapid growth and bioassays with tobacco tissue cultures. Physiol Plant 15: 473497.

Thambiraj, J. and S. Paulsamy, (2012). Rapid in vitro multiplication of the ethnomedicinal shrub, Acacia caesia (L.) Willd. (Mimosaceae) from leaf explants. Asian Pacific Journal of Tropical Biomedicine S618 - S622.
Jebakumar, M. and M. Jayabalan, (2000). Plant cell Biotechnol Mol Biol 1: 37-40.

Hussain, M. and M. Anis, (2006). Acta physiol plant 28: $325-330$.

Raja, H. David, and D.I. Arockiasamy, (2008). Plant cell Tissue and Organ Culture 18: 1-6.

Faisal, M. and M. Anis, (2003). Plant cell Tissue and Organ Culture 75: 125-129.

Sujatha, M. and T.P. Reddy, (1998). Differential Cytokinin effects on the stimulation of in vitro shoot proliferation from meristematic explants of castor (Ricinus Communis L.). Plant cell Rep 17: 561-566.

Ahn, Y.J., L. Vang, T.A. Mc Keon and G.Q. Chen, (2007). High -frequency plant regeneration through adventitious shoot formation in castor(Ricinus communis L.). In vitro Cell Dev Bio-plant 43: 915.

Alam, I., S.A. Sharmin, S. Chandra Mondal, M.D. Jahangir Alam, M. Khalekuzzaman, M. Anisuzzaman and M. Firoz Alam, (2010). In vitro micropropagation through cotyledonary node culture of castor bean (Ricinus communis L.). Australian Journal of Crop Science 4 (2): 8184.

Ramanathan, T., K. Satyavani and S. Gurudeeban, (2011). In vitro plant regeneration from leaf primordia of gum-bearing tree Aegle marmelos. E- International Scientific Research Journal 3 (1): 47-50. 